ÇOMÜ Uluslararası Sosyal Bilimler Dergisi 3(1), 113-124, 2018

COMU International Journal of Social Sciences 3(1), 113-124, 2018

\title{
Tanzimat Edebiyatının Epistemolojisine Eleştirel Bir Bakış: Düalite ve Öğretmen-Yazar/Öğrenci Okur İlişkisi
}

Bilgin GÜNGÖR*

Öz

Tanzimat döneminin düşünsel yapısı ve edebi estetiği üzerine Ziya Gökalp’ten Ahmet Hamdi Tanpınar'a; Hilmi Ziya Ülkenıden Mehmet Kaplan'a kadar pek çok aydın çeşitli yorumlar getirmişlerdir. Bu yorumlar, barındırdıkları çeşitli tezlerle birlikte, çoğunlukla "düalite" ekseninde yürür. Tanzimat dönemi -ve sonraki dönem- aydınlarının kaleme aldığı edebi ve edebiyat-dışı eserler göz önünde bulundurulduğunda bu "postula"nın somut bir temeli olduğunu söyleyebilmek mümkündür. Bununla birlikte Jale Parla, Babalar ve Oğullar (Tanzimat Romanının Epistemolojik Temelleri) adlı eserinde, Tanzimat döneminin düşünsel evreni üzerine farklı yorumlar getirmiş ve böyle bir evren için "düalite" kavramının yersiz olduğunu; bu dönemin aydınlarının ve romancılarının eserlerinde Doğulu değerlere evcilleştirilmiş Batılı değerlerin -en azından Beşir Fuad'a kadar- sorunsuzca eklemlendiğini ileri sürer. Ayrıca bu dönem romancıları ve roman kahramanları ile okur kitlesi arasında "baba-oğul" ilişkisine benzer bir ilişkinin somutlaştığııı; Tanzimat Fermanı ile yetkileri kısıtlanan padişahın toplum karşısındaki "baba”lığını bu dönemde romancıların -ve genel Tanzimat aydınlarının- üstlendiğini belirtir. Şüphesiz Parla'nın söz konusu tezleri, kısmen somut bir zemine otursa da, çalışmamız sırasında da görüleceği gibi, bu dönem romancılarının -ve genel olarak Tanzimat aydınlarının- eserleri göz önünde bulundurulduğunda, oldukça "yanlışlanabilir" bir konumda belirir.

Anahtar Kelimeler: Tanzimat dönemi, Tanzimat romanı, düalite, yazar-okur ilişkisi.

\section{A Critical Overview of Epistemology of Tanzimat Literature: Duality and Teacher-Author/Student-Reader Relationship}

\begin{abstract}
Many intellectuals from Ziya Gökalp to Ahmet Hamdi Tanpınar and Hilmi Ziya Ülken to Mehmet Kaplan brought various interpretations on the intellectual structure and literary aesthetics of the Tanzimat period. These comments, along with the various theses they hold, often walk on the axis of "duality". It is possible to say that this "postulat" is a concrete foundation when the literary and non-literary works received by the intellectuals of the Tanzimat period - and later periods - are taken into consideration. Jale Parla, in Babalar ve Oğullar (Tanzimat Romanının Epistemolojik Temelleri), however, brought different interpretations of the intellectual universe of the Tanzimat period and concluded that the concept of "duality" is unfounded for such a universe; argued that in the works of the intellectuals and novelists of this period, the domesticated Western values of Oriental values - at least to Beşir Fuad - were articulated without problems. In addition, this
\end{abstract}


period embodies a similar relationship between the heroes of novels and novels and the readership of the "father-son" relationship, and indicates that the sultan, who was restricted by Tanzimat Ferman and the authority of the sultan, assumed the "father" of the society in this period and the romans and generally Tanzimat intellectuals. Undoubtedly, even if Parla's theses are partially tangible, this period can be seen as a "falsifiable" position when the works of the novelists - and generally Tanzimat intellectuals - are taken into consideration. In this review, we will focus on the disproportionate aspects of the theses, and some determinations will be made on the author-reader relationship of the period.

Key Words: Tanzimat period, Tanzimat novel, duality, author-reader relationship.

\section{GíRiş}

Jale Parla, Babalar ve Oğullar (Tanzimat Romanının Epistemolojik Temelleri) adlı eserinde, Tanzimat döneminin hâkim epistemolojik yönsemeleri ile ilgili olarak gerek yakın dönem tarihyazımındaki (historiography) gerekse de edebi eleştiri geleneğindeki yaygın bir yargıyı yapıbozuma uğratma çabasına girişir. Mehmet Ali Kılıçbay, Hıfzı Veldet Velidedeoğlu gibi aydınların ilgili düşüncelerinden yola çıkan Parla, özet olarak, Tanzimat düşüncesinin -Michel Foucault'nun terminolojisinden hareketle ifade etmek gerekirse"epistemesi"nin ${ }^{1}$ ("epistéme") düaliteye maruz kalmadığını, geleneksel Doğulu-i̇slâmî tandansı imlediğini ve Batlılaşmanın makul ölçülerde söz konusu epistemeye eklemlendiğini dile getirir. Bu bağlamda, bütün Tanzimat aydınları gibi Tanzimat romancılarının da -Tanzimat Fermanı sonrası padişah yetkilerinin kısıtlanmasından ötürü- bir "baba" figürü dâhilinde söz konusu "episteme" yi (ki Parla bunu “mutlak metin" olarak adlandırır) eserlerinde (Parla, 2016: 29) çeşitli şekillerde işlediğini ve hem roman kahramanlarını hem de halkı bir "oğul" gibi konumlandırdıklarını düşünür. Öyle ki Parla'ya göre;

“(...) bu yazarlar her şeyi bileceklerdir; örneğin yarattkları kişilerin tüm düşünceleri, duygu ve istekleri alabildiğine saydamdır onlar için ve aynı saydamlıkla yansıtılır. Evet, her şeyi öğreteceklerdir; hem de sık sık olay örgüsüne müdahale edip okurun doğru öğrendiğinden emin olana dek. Evet, yargılayacaklardır, hatta diyebiliriz ki roman yazmalarındaki temel amaç 'kalb-i insaniyet'; 'tabiat-ı beşer'; 'ahlâk-ı beşer'; 'ahlâk-ı cemiyet'; 'havass-ı beşer' diye kategorize ettikleri genellemeler üzerinde yargılarını iletmektir." (Parla, 2016: 49-50)

Parla, gerek "mutlak metin"in etkisinin gerekse de söz konusu metinde beliren epistemenin doğrultusunda ortaya çıkan "baba-oğul ilişkisi"nin, intiharını "ikarus" mitiyle metaforik olarak anlattğı Beşir Fuad’a kadar sürdüğünü düşünür; dolayısıyla "düalite"nin etkinliğinin Beşir Fuad’la başladığını ilân eder gibidir (Parla, 2016: 111-121).

Osmanlı toplumunun dinî bir idealizm ile taçlanan despotik yapısının, Ahmet Hamdi Tanpınar'ın "medeniyet krizi” olarak adlandırdığı (Tanpınar, 1977: 101) erken Batılılaşma süreci sırasında, yani dini idealizme dönük "meşrulaştırım” ın ("legitimation") ${ }^{2}$ büyük zarar gördüğü dönemde dahi etkisini sürdürdüğü ve bunun diğer üstyapı olgularında,

1 Foucault'nun terminolojisinde episteme, bir çağın söylem biçimlerinin özü veya söz konusu söylemlerin dayandığı temel paradigma olarak belirir. Bkz. Michel Foucault, Bilginin Arkeolojisi, Çev. Veli Urhan, Birey Yayınları, İstanbul 1999, s. 242-251.

2 Postmodern düşünürlerden Jean-François Lyotard'dan itibaren düşünce dünyasında yer bulan meşrulaştırım; daha çok epistemolojik yorumların faydaları ve idealleri üzerine bir dayanak noktası atfetme çabasını imler. Bkz. Jean-François Lyotard, The Postmodern Condition: A Report on Kowledge, Trans. Geoff Bennington- Brian Massum, Manchester University Press, Manchester 1984, p. 6-9. 
yani düşünsel alanlarda da yansıma alanı bulduğu; dolayısıyla edebiyatta da söz konusu despotik yapının izlerinin barındığı konusunda şüphe yoktur. Bu bağlamda Parla'nın "baba-oğul ilişkisi" metaforu aracılığıyla öne sürdüğü olgu, Tanzimat romanında -ve hatta genel olarak Tanzimat edebiyatında- zaman zaman görülebilir. Fakat Parla'nın tezleri, pek çok yönden "eleştirilebilir" bir konumdadır. Çünkü Tanzimat dönemi ve sonrasının gelişmelerini aklımıza getirdiğimizde, söz konusu tezlerin büyük ölçüde temelsiz kalabileceğini düşünmekteyiz. Bu incelemede, Parla'nın söz konusu tezlerinin -bizce- aksayan yönleri üzerinde durmakla birlikte Tanzimat döneminde yazar-okur ilişkisi üzerine bazı tespitlerde bulunmaya çalışacağız.

\section{1. "MUTLAK METIN"IN İhLÁLi}

Öncelikle, Parla'nın "baba-oğul ilişkisi” metaforu etrafinda dile getirdiği despotik-otokratik "mutlak metin" anlayışının Tanzimat döneminde izlerine rastlanılması, o dönemin temel "episteme"sinin "düalite" ekseninde oluştuğu gerçeğini değiştirmez. Bu dönemin (ve sonraki dönemlerin) aydınları, farklı ölçülerde de olsa, "mutlak metin"in sınırlarını net bir şekilde ihlâl ederler. Bu hususta ilk olarak Tanzimat dönemi aydınlarının bazı eserlerine yönelmek son derece aydınlatıcı olacaktır. Sözgelimi İbrahim Şinasi Efendi, inançlı olsa da, Tanzimat'ın öncüsü olan sadrazam Mustafa Reşid Paşa'yı "medeniyet resulü"; onun vücudunu ise "vücûd-ı mu'ciz" olarak adlandırır ki böyle bir tavır, "mutlak metin"in kapsadığı Sünnî-ïslâmî ölçütlere de padişah merkezli devlet felsefesine de uymaz:

\section{"Aceb midir medeniyyet resûlü dense sana}

Vücûd-ı mu'cizin eyler ta'assubu tahzîr" (Şinasi, 2005: 11).

Nuri Sağlam'ın da belirttiği gibi bu dizelerde "Şinasi, Allah'ın Kur'ân-ı Kerîm'de sadece Hz. Muhammed için kullandığı 'resul' sıfatını Mustafa Reşit Paşa'ya yakıştırmak suretiyle 'resul' sıfatının kutsallığını ve bu sıfatın yalnız Hz. Muhammed'e ait oluşuyla da islâm inancındaki hususî yerini bir anda sarsmayı hedefle[-er]." (Sağlam 2013: 68) Nâmık Kemal'in "Yunus ilahisi"ne benzettiği (Göçgün, 2009: 20) "Münacât" şiirinde ise Şinasi, bu kez doğrudan Tanrı'ya yönelik "mutlak metin" in sınırlarının ötesine geçen bir yoruma yönelir ve Tanrı́nın varlığını, Fransız aydınlanmacıların temel ölçüt saydığı akıl ile ispatlama çabasına girişmek ister:

\section{"Vahdet-i zâtına aklımca şehadet lâzım}

Cân u gönlümle münâcât u ibâdet lâzım" (Şinasi, 2005: 5)

Şinasi ile aynı dönemin aydınlarından olan Sadullah Paşa ise, "Ondokuzuncu Asır" adlı şiirinde, akıl ile birlikte bilim ve ilerlemeyi "zamanın ruhu"nun birer yükselen değeri olarak görmekle birlikte, "beka-yı cem'iyyat" için benimsediği dini kaidelere hiç değinmeden söz konusu değerleri benimsemeyi şart koşarak geleneksel inancı ve devlet felsefesini kapsayan "mutlak metin"i adeta yok sayar:

\section{"Zamân zamân-ı terakki cihân cihân-ı ulûm}

Olur mu cehl ile kabil beka-yı cem'iyyat" (Kaplan, 2007: 72)

Ziya Paşa ise geleneksel İslâm anlayışına sıkı sıkıya bağlı bulunsa da "Terci'-i Bend"de hayat ve onun düzeni karşısında son derece kötümser bir bakışı somutlaştırır ki Mehmet Kaplan'ın da vurguladığı gibi bu şiirde Ziya Paşa, devlette ve "kâinatta nizamdan 
çok nizamsızlık" (Kaplan 2007: 59) gördüğünü dile getirmek ister. Bu durum ise, kabul edilmelidir ki, "mutlak metin" sınırları etrafinda olabilecek veya gelenekte mevcudiyeti bulunabilecek bir olguyu imlememektedir. "Mutlak metin"deki Sünnî-İslâm anlayışında, bilindiği gibi, kötümser olmak, Tanrı́nın varlığını inkâr noktasına yaklaşmaya vesile olması sebebiyle doğru bir düşünce biçiminden sayılmaz. Yine söz konusu anlayış, kâinat, mükemmel bir şekilde yaratılmış, şaşmaz ve mutlak bir "nizâm" içerisinde görür ki Osmanlı'nın egemen ideolojisindeki “nizâm-ı âlem” düşüncesi de bu temelde yükselir.

Bu noktada ayrıca Robert P. Finn'in de dikkat çektiği olguya yönelmek gerekir. Finn'in de belirttiği gibi bu dönem romancılarının eserlerinde kahramanların camiye girdiği veya herhangi bir ibadette bulunduğu pek görülmez. (Finn, 2013: 119)3 Ayrıca bu kahramanların, Turfanda mı Turfa mı? romanının kahramanı Mansur Bey dışında hemen hemen dindar bir kişilik portresine sahip olduğu söylenemez.

Tanzimat aydınlarının "mutlak metin”i ihlâl edişlerindeki sert tutumlarına, daha doğru bir söylemle belirtirsek "düalite"ye düşüşlerine yönelik örnek vermek amacıyla, bu dönemde, özellikle ırk nazariyelerine ve kolonyal süreçlere değinen metinlere bakmak da faydalı olacaktır. Nitekim bu metinlerde Tanzimat aydınlarının kolonyalist söylemleri ne şekilde benimsediği rahatlıkla görülebilir. Sözgelimi, Tanzimat döneminin önemli aydınlarından olan Münif Paşa, bir yazısında, kolonyalistlerin ırkçı söylemini tekrar ederek, "beyaz" Kafkas ırkının "siyah" ırka üstünlüğünü savunur ki bu, tüm ırkları eşit gören bir inancın ve bütün gayrimüslim ırkları reaya çatısı altında eritmeye gayret eden bir imparatorluğun mensubu aydın için son derece cesur bir iddiadır:

"Umûmen nev-i insanın san'at-ı kitâbet tahsiline kabiliyeti derkâr ise de ecnâs ümemin teallüm-ı ulûma isti'dâdı mütefâvittir. Türk ve Arab ve Acem ve Rum ve tavâif-i efrencîden ibaret olan Kafkas cinsi bu babda en ziyâde müstaîd olup, zenci taifesinin şekil ve hilkatleri iktizasınca ulûm-ı riyaziye ve hikemiye mesâik-i dakikasını fehm ve idrâkden aciz olduklarının bi't-tecrübe malum olduğu rivayet kılınır."

Tanzimat romanının öncülerinden olan Ahmet Midhat Efendi ise Rikalda yahut Amerika'da Bir Vahşet Âlemi adlı romanında, Aztek kalıntısı bir kabilenin yaşayışını ve mekânını betimlerken, kolonyalist-şarkiyatçı söylemlerin ırkçı teorilerine başvurmaktan geri kalmaz. Söz konusu kabilenin yaşadığı yerler, İngiliz kolonyalistlerin "medenileştirme" sürecinden evvel "vahşet-âbâd"tır; hatta bundan da ötedir. Öyle ki, bu vahşi ortamı okurlar dahi gözünde canlandırmakta zorluk çekebilirler:

“Vakıa şimdilerde Missouri nehrinin sahilleri Avrupa'nın Loire ve Rhin seyahili gibi muntazam çiftlikler, köyler, kasabalarla müzeyyen ve eyâdi-i maharetle işlenir tarlalar, çayırlar, bahçeler, bağlarla mücehhez bir mâmure-i ferah-fezâ ise de hikâyemizin zaman-i

3 Finn'in bu husustaki düşüncelerini detaylı bir şekilde vermek konumuz açısından faydalı olacaktır. Finn'e göre Tanzimat romanlarında "belirgin bir biçimde göze çarpan bir başka özellik de, etkin din öğesinin yokluğudur. Turfanda mı Yoksa Turfa mı?, İslam dinine ilişkin bazı tartş̧malara, en azından öğrenim açısından dine yer verir, öbür romanlarda bu konuda genel bir suskunluk vardır. Kişilerden hiçbiri camiye gitmez sözgelimi; 'Allah' adı ara sıra geçse de, roman başkişilerinin gündelik yaşamlarında Muhammed'in ilkeleriyle yönetilmedikleri apaçık ortadadır." Robert P. Finn, Türk Romanı: illk Dönem, 1872-1900, Çev. Tomris Uyar, Agora Kitaplığı, İstanbul 2013, s. 119.

4 Bu hususta ayrıntılı bilgi için bkz. Altuğ, Fatih (2014). "19. Yüzyıl Osmanlı Edebiyatında İmparatorluk, Medeniyet, Yerlilik, Yaban(cı)lık ve Din", Tanzimat ve Edebiyat: Osmanlı İstanbul'unda Modern Edebi Kültür, Haz. Mehmet Fatih Uslu-Fatih Altuğ, İstanbul: Türkiye İ̧ Bankası Kültür Yayınları, s. 77. 
güzerânı olan geçen on sekizinci asr-ı milâdî evâhirinde şimdiki mamuriyet oralar için henüz hayal ve hatrda bile tasavvur olunamazdı. Oraları adeta vahşet-âbâd yerlerden olup şimdiki ahâlî-i mütemeddineye bedel Aztek denilen kavm-i kadimin bakıyyesi ellerinde bulunurdu.

Lâkin sevâhil-i mezkûrenin ahvâlini tasvir için 'vahşet-âbâd' diye istimal etmiş eylemiş bulunduğumuz tabîr acaba kâfi midir? Acaba karilerimiz bu tabir üzerine gözlerini yumarak şu Missouri nehri sahillerinin hâl-i vahşeti neden ibaret bulunduğunu hayalleri önünde tecessüm ettirmek istedikleri zaman bu sa'ylarında ne dereceye kadar muvaffak olabilirler?" (Ahmet Mithat Efendi 2003: 625)

Bu noktada son olarak Tanzimat aydınının, "mutlak metin" eksenindeki eski edebiyat geleneği karşısında doğrudan ortaya koydukları katı tutuma değinmek faydalı olacaktr. Bilindiği gibi özellikle Nâmık Kemal ve (ilk dönemlerini baz alırsak) Ziya Paşa, divan edebiyatının gerçekçi ve ulusal bir niteliği bulunmadığını ifade ederek edebiyatın yönünü Doğu'dan Bati'ya çevirmenin doğru olduğunu öne sürmüşlerdir. ${ }^{6}$ Böylelikle "mutlak metin"in en azından estetik/sanatsal eksenini tamamıyla redde kadar varmışlar ve söz konusu metinle hemen hemen zıt bir epistemoloji temelinde yükselmiş yeni (Batılı) estetik kaideleri hem uygulamaya hem de teorik olarak betimlemeye yönelmişlerdir. Parla, "mutlak metin"e bağlı kaldığını iddia ettiği Tanzimat edebiyatçılarının Divan edebiyatına karşı koyuşunun söz konusu temel tezle olan çelişkisini aşmak için Harold Bloom'un "anxiety of influence" ("etkilenme endişesi") teorisinden hareketle, yani her "oğul"un "baba" yı aşmaya çalışmasıyla somutlaşan edebiyat tarihi mantığını öne çıkaran bir tezden faydalanır.7 Fakat Tanzimat yazarının "mutlak metin"e bağlı kaldığı hâlde böyle derin bir "etkilenme endişesi" duyması mümkün olmasa gerek. Kutsiyet taşıyan ve "mutlak metin"e göbekten bağımlı olan eski edebiyat anlayışı karşısında aynı metin doğrultusunda kalem oynatan bir Tanzimat edebiyatçısına, belki de en fazla Şeyh Galib'in Nabi karşısındaki tavrına ${ }^{8}$ benzer bir özgünlük arayışına girişmek düşer. Aksi hâlde "mutlak metin"in sınırları dışındaki bir düşünce yapısının çerçevesinde hareket etmek gerekir ki Tanzimat edebiyatçısında veya aydınında durum da budur.

Görüldüğü gibi Tanzimat aydınlarının metinlerinde, “mutlak metin”in sınırlarına yönelik

5 Ahmet Midhat Efendi, Bütün Eserleri: Romanlar XII: Rikalda yahut Amerika'da Bir Vahşet Âlemi, Haz. M. Fatih Andı, Türk Dil Kurumu Yayınları, Ankara 2003. s. 625.

6 Nitekim Bilge Ercilasun'un da belirttiği gibi bu dönem edebi eleştirinin temel mantı̆̆ da eskinin yerilmesi, yeninin övülmesine dayalıdır. Bkz. Bilge Ercilasun, "Servet-i Fünûn Edebiyatında Tenkit", Servet-i Fünûn Edebiyat, Haz.İsmail Parlatır, Akçağ Yayınları, Ankara 2006, s. 492.

7 Bloom'un söz konusu teorisine göre edebiyat alanında şairler ve yazarların gelenekle olan ilişkisi adeta Oedipal bir kompleks çerçevesinde somutlaşır. Her şair ve yazar, geleneği aşmak, onun etkisini kırmak; yani "baba” yı ortadan kaldırıp kendisini var etmek idealiyle eserler üretir. Bu hususta güçlü bir özgünlük yaratırsa kanonlaşır; aksi hâlde geleneğin içerisinde sıradan bir takipçi konumuna düşer. Bu hususta detaylı bilgi için bkz. Harold Bloom, Etkilenme Endişesi: Bir Şiir Teorisi, Çev. Ferit Burak Aydar, Metis Yayınları, İstanbul 2008, s.9-42. Harold Bloom, Batı Kanonu: Çağların Ekolleri ve Kitapları, Çev. Çiğdem Pala Mull, İthaki Yayınları, İstanbul 2014, s. 21-46.

8 Şeyh Galip, Hüsn ü Aşk'ın "Der beyân-ı sebeb-i te'lif” bölümündeki "Bezm ehl-i serâ-ser etti ikrâr/ Bu kavli muvâfakatla tekrar//Bu gâyete erdi kim meâli/Tanzîrinin olmaz ihtimâli//"Ol rıtl bana girân göründü/Bir suret-i imtihân göründü// (...)Aldım o hevesle kilki deste/Bu nazmı dedim şikeste beste" beyitlerinden de anlaşılacağı gibi, mesnevisini Nabi'nin aşılmaz görünen Hayrabad'ını aşmak amacıyla kaleme almıştır. Bkz. Şeyh Galip, Hüsn ü Aşk, Haz. Orhan Okay-Hüseyin Ayan, Dergâh Yayınları, İstanbul 2000, s.38-46. 
Beşir Fuad'dan da önce beliren ihlâller, hem Sünnî-Islâm akidelerine hem de geleneksel devlet felsefesine son derece ters düşer. Bu ihlâlleri, "mutlak metin"e uyumlu -veya Parla'nın deyişiyle "evcilleştirilmiş" (Parla, 2016: 23)- şekilde eklemlenen bir Batılılaşma programının normal görüngülerinden saymak da doğru bir yaklaşım olarak görülemez (nitekim Tanzimat aydınlarının, "meşruti monarşi" dışında Batı'dan gelen "yenilik"leri dinen veya "mutlak metin"e uygun bir şekilde temellendirerek ortaya koydukları pek de görülmez ki uyumluluktan veya "evcilleştirmek"ten bahsetmek bu bağlamda mümkün olmaz). Yukarıdaki açıklamalardan da anlaşılabileceği gibi burada, iki farklı "mutlak metin", yani hem Doğulu-i̇slâmî "mutlak metin" hem de Batllı-Laik "mutlak metin" bir çaţ̧ma hâlindedir. Fakat bu durum, Tanzimat aydınlarının sadece kitaplarında, makalelerinde değil; aynı zamanda çeşitli aktivitelerinde de belirir. Nitekim Tanzimat dönemi; Osman Hamdi Bey'in, Üsküdarlı Hoca Ali Rıza'nın romantik resimler ürettiği; daha evvel heterodoks gruplar tarafindan yapılan ihtilal hareketlerinin artk Jön Türk mensubu aydınlar tarafindan da planlanmaya başladığı; kamuoyunun gazete aracılığıyla canlandırımaya ve yönetime ortak edilmeye çalışıldığı bir dönemdir. Dolayısıyla Tanzimat dönemi, Doğuluİslâmî bir "mutlak metin"in egemenliğine dayalı bir düşünsel evrenin değil, daha çok kaos şeklinde açığa çıkan ve Cumhuriyet'in ilk yıllarına kadar büyük oranda etkisini sürdüren bir düşünsel "düalite" evreninin egemenliği çatısı altında düşünülmelidir.

\section{BABA ilLE OĞUL, ÖĞRETMEN ilLe ÖĞRENCi, ÖĞRETMEN-YAZAR íle ÖĞRENCI-OKUR}

Parla, yukarıda da belirttiğimiz gibi, Tanzimat aydınları gibi Tanzimat romancılarının da geleneksel Doğulu-i̇slâmî "mutlak metin"den yola çıkarak eserler oluşturduğunu; bu hususta geleneksel otorite olgusunu romanlarında hissettirdiğini ve dolayısıyla da hem yazar ile roman kahramanı arasında hem de yazar ile okur arasında "baba-oğul ilişkisi" metaforuyla açıklanabilecek bir hegemonik ilişki biçiminin doğduğunu dile getirir.

Öncelikle, yazar karşısında roman kahramanlarının, Parla'nın deyişiyle "tüm düşünceleri[nin], duygu ve istekleri[-nin] alabildiğine saydam" olması, "aynı saydamlıkla yansıtılır" (Parla 2016: 49) bir nitelikte bulunması ve söz konusu kahramanların belli değerler etrafinda cezalandırılması/mükâfatlandırılması -belli açılardan bakıldığında- bir "baba-oğul ilişkisi" çerçevesinde düşünülebilir. Fakat bu şekilde düşünüldüğünde, tutarlı olmak adına, hemen hemen 18. yüzyılın başından 20. yüzyılın başına kadar bütün romanlardaki yazar-okur ilişkisini bir "baba" ve "oğul" metaforu temelinde açılamak gerekir. Nitekim yaklaşık iki yüz yıllık roman geleneğinde (romantik ve realist roman evreninde), yazarın kurgusal düzlemde çoğunlukla bir "Tanrısal anlatıı”" konumunda bulunduğu barizdir. (Moran 2010: 237-242) Balzac için Goriot Baba'nın, Eugénie Grandet'ın; Tolstoy için Anna Karenina'nın, Nataşa Rostova'nın bütün duygularıyla düşünceleri "saydam"dır ve aynı saydamlıkla yansıtılır. Bununla birlikte her "Tanrısal anlatıcı", kahramanlarını belli değerler doğrultusunda cezalandırılabilir veya mükâfatlandırılabilir -ki Gennady Nikolayeviç Pospelov buna, "karakterlerin düşünsel yorumlanışı" adını verir (Pospelov,

9 Kaldı ki "meşruti monarşi”yi temellendirirken Tanzimat aydınlarını harekete geçiren etkenin "mutlak metin"in ilkelerinden çok kamuoyunu ürkütme korkusu olduğu da düşünülebilir. Nitekim Yalçın Küçük, "meşruti monarşi” "yi İslâmi tandanslı bir söylemle savunanların başında gelen Namık Kemal ve Ziya Paşa'nın kaleme aldıklarından hareketle Tanzimat aydınlarının böyle bir söylem geliştirmesinin temelinde halktan kaynaklı "Tanzimat’ın tepkisini duy[-ma]”nın olduğunu düşünür. Bkz. Yalçın Küçük, Aydın Üzerine Tezler 1, Tekin Yayınevi, İstanbul 1990, s. 623. 
2005: 112-113). Dolayısıyla Tanzimat romancısı için de bu şekilde bir cezalandırma/ mükâfatlandırma sistemine dönük tercihin doğal görülmesi gerekir. Üstelik bu cezalandırma/mükâfatlandırma sisteminin de "mutlak metin" çerçevesinde değil, yazarların "düalite" şeklinde beliren fikirleri çerçevesinde olduğu ortadadır. Yazarlar, Parla'nın iddia ettiğinin aksine, kahramanlarını her zaman "süflî lezzetler"den uzaklaşmalarına/ yakınlaşmalarına göre cezalandırmazlar/mükâfatlandırmazlar; bazen cezalanlandırma/ mükâfatlandırma, söz konusu yapının dışında gerçekleşebilir. Şemsettin Sami'nin Talat'ı ve Fitnat'ı ölüme mahkûm etmesi, "mutlak metin"deki değerlerin aksine bir yol izlendiği için değil, tam aksine, "mutlak metin" çerçevesinde düşünülmesi gereken "görücü usulü evlilik"e uyulmak zorunda kalındığı içindir. Samipaşazade Sezai'nin Dilber'in intiharını bir "hürriyet" olarak betimlemesinin de "mutlak metin"le olan uyuşmazlığı ortadadır: Bilindiği gibi İslâmî anlayışta intihar, bir "hürriyet"e kavuşma vesilesi değil; Tanrı tarafindan cezalandırılacak yanlış bir harekettir. Midhat Efendi'nin Rakım Efendi'yi zenginlik ve başarı ile mükâfatlandırmasına gelirsek, burada da "mutlak metin"e uymanın faydalı sonuçlarından daha çok, bir "protestan ahlâkı"na uymanın faydalı sonucunu görürüz. Rakım Efendi, dindar olduğu ve geleneğe sıkı sıkıya bağlı bulunduğundan ötürü değil (ki Jozefino ile flört etmesi, içki kullanması gibi durumlar Rakım Efendi'nin "mutlak metin"e belli ölçülerde uzak durduğunu gösterir); para kazanmak için çalışkanlığa ve rasyonaliteye dayalı bir mikro-ekonomi kurguladığı için zengin ve başarılı olmuştur.

Romanlardaki ve genel olarak edebiyattaki yazar-ile okur ilişkisine gelirsek; gerek Tanzimat edebiyatında gerekse de sonraki dönem edebiyatlarında yazar ile okur arasındaki ilişki biçiminin hükmetmek veya yönetmekten çok, öğretmek ve eğitmek temelinde somutlaşth̆̆ını, dolayısıyla "baba-oğul ilişkisi" metaforunun bu ilişki biçimini karşılamada yetersiz olduğunu; "öğretmen-öğrenci ilişkisi" metaforunun bu bağlamda kullanılmasının daha doğru olabileceğini dile getirmek gerekir. Nitekim "baba", bilgi vermekten ve eğitmekten çok, cezalandırma ve bir baskı kurma; ilerletmekten çok sabit tutma ve nizâmı bâki kılmanın bir figürüdür. "Baba" figürünün -hele de Doğu tipi despotik toplumlarda- bilgi verme, eğitme ve ilerletme gibi bir misyonu bulunmaz; bu misyon, olsa olsa "öğretmen" figürüyle açıklanabilir. Louis Althusser'in, Antonio Gramsci'nin "hegemonya" teorisindeki "kuvvet-rıza" diyalektiğine dayalı olarak ortaya koyduğu devlet aygıtları gruplandırmasını bir benzetme öğesi olarak ele alırsak, "baba"nın "baskı aygıt"na; "öğretmen" in ise daha çok "ideolojik aygıt"a benzediğini dile getirebiliriz. ${ }^{10} \mathrm{ilki}$ kuvvetle, "baskı"yla; ikincisi ise eğitimle, "rıza"yla işler. Dolayısıyla Tanzimat romancıları -ve genel olarak Tanzimat aydını-, bir "baba"dan çok, bir "öğretmen” figürü olarak okurun karşısına çıkarak kuvvet ve baskıdan çok eğitimle, rızayla onun bilinci üzerinde muamelede bulunur. Ülkenin modernleşmesine ve medenileşmesine katkı sağlamak için Tanzimat -ve daha sonraki dönemlerin- aydını bir inisiyatif alır. Bu bağlamda Tanzimat döneminden itibaren yazar ile okur arasındaki ilişkisi, klasik yazar-okur ilişkisinden öte

10 “Avrupa Marksizmi”nin öncülerinden Antoni Gramsci, toplumsal formasyonda burjuvazinin proletarya üzerinde bir yandan "kuvvet"e bir yandan da "rıza"ya dayalı olarak hegemonya kurduğunu düşünür. Bkz. Antonio Gramsci, Hapishane Defterleri, Çev. Adnan Cemgil, Belge Yayınları, İstanbul 2014, 341-342. "Yapısalcı Marksizm"in öncülerinden Louis Althusser, Gramsci'nin bu tezine dayanarak, hegemonik işlev üstlenen devleti iki aygıtsal kısımda düşünür: Illk kısımda "devletin baskı aygıtları" (polis, asker vs.); ikinci kısımda ise "devletin ideolojik aygıtları" (okul, televizyon vs.) vardır. Devlet, Althusser'e göre, burjuvazinin bir hegemonya unsuru olarak, bir yandan silahlı güce, diğer yandan ise ideolojik güce dayanır. Bkz. Louis Althusser, İdeoloji ve Devletin İdeolojik Aygıtları, İstanbul 2014, 55-64. 
bir boyut kazanır; daha doğrusu klasik yazar-okur ilişkisinden çok farklı olarak, adeta bir öğretmen-öğrenci ilişkisi çerçevesinde somutlaşır. Bu ilişkide -söz konusu metafordan hareketle bir adlandırmaya başvurarak ifade edersek- halkı aydınlatmak, ülkeyi "muasır medeniyetler" seviyesine çıkarmak için eğitimci sıfatındaki bir öğretmen-yazar ile söz konusu öğretmeninin "kıssadan hisse"leriyle çağı yakalaması düşünülen öğrenci-okur mevcuttur. Şinasi'nin "Tercümân-ı Ahvâl Mukaddimesi”ni bu bağlamda, söz konusu ilişkinin sadece gazete üzerinden değil, bütün bir neşriyat üzerinden yürütülen antlaşması saymak mümkündür. Bu mukaddimede Şinasi, gazetenin temel misyonunun hem içte hem de dıştaki olayları ve durumları halkın anlayacağı bir dille haber verme gibi bir misyon yüklendiğini ve zaten gazetenin adının da buradan geldiğini bildirerek, adeta Tanzimat aydının çoğunluğunun ve okurların rolünü ilan eder:

"Imdi işbu gazete ahval-i dâhiliye ve hariciyeden müntehap bâzı havadisi ve maarif-i mütenevvia ile sair mevadd-i nâfiaya dair mebahisi neşr-ü beyana vasıta olacağından nâşî, Tercüman-ı ahval ünvanı ile tesmiye olunmak münasip görüldü. Ta'rife hâcet olmadığı üzre kelâm, ifade-i meram etmeğe mahsus bir mevhibe-i kudret olduğu misillû, en güzel icad-i akl-ı insanî olan kitabet dahi kalemle tasvir-i kelâm eylemek fenninden ibarettir; bu itibar-i hakikate mebnî giderek, umum halkın kolaylıkla anlayabileceği mertebede, işbu gazeteyi kaleme almak mültezem olduğu dahi makam münasebeti ile şimdiden ihtar olunur."(Şinasi, 2005: 166)

Herkesin anlayabileceği sade bir dille hem içerideki hem de dışarıdaki durum ve olaylar hakkında bilgi verme, Tanzimat-ve kısmen sonraki dönem- aydınlarının ortaya koyduğu eserlerin de bir anlamda temel mantalitesini verir. Ahmet Midhat Efendi'nin eserlerinin gerek iktisadi (Müşahedat, Acaib-i Âlem vs.) gerek sosyolojik (Felatun Bey ve Rakım Efendi, Avrupa'da Bir Cevelan vs. ) gerekse de teknolojik bilgilerle (Dürdane Hanım, Ahmet Metin ve Şirzat vs. ) dolu olduğunu; Namık Kemal'in "hürriyet"in nimetlerini ("Hürriyet Kasidesi") ve tarihsel kişiliklerin üstün vasıflarını (Cezmi) edebi eserler vasıtasıyla halka yeniden hatırlatmaya çalıştığını; Samipaşazade Sezai'nin kölelik kurumunun zararlarını halkın dikkatine bir roman formatında sunduğunu (Sergüzeşt) bu bağlamda hatırlayabiliriz.

Bu noktada eklemek gerekir ki, edebiyat evrenindeki öğretmen-yazar ile öğrenci-okur ilişkisinin 1950'lere kadar büyük ölçüde devam ettiğini öne sürmek de mümkündür. Nitekim Türk edebiyatından bu bağlamda verilebilecek pek çok örnek bulunmaktadır. Sözgelimi Tevfik Fikret, oğlu Halûk'un şahsında bütün genç nesli, "Tanrılar"dan (Batt'dan) insanlara (Osmanlı'ya) "ateş"i (bilim ve teknolojiyi) getirecek bir "Promete" olarak görür ve söz konusu nesle yönelik yönlendirmelerde bulunur:

"Müştâk-ı feyz u nûr olan âti-i milletin

Mechûl elektrikçisi, aktâr-ı fikretin

Yüklen getir - ne varsa - biraz meskenet - fiken,

Bir parça rûhu, benliği, idrâki besleyen

Esmâr-ı bünye-hıyzini; boş durmasın elin.

Gör dâimâ önünde esâtir-i evvelin 
Gökten dehâ-yi nârı çalan kahramâanını...

Varsın bulunmasın bilecek nâm ü şânını!" (Fikret, 2010: 80-82)

Aynı dönemlerde Mehmet Âkif ise, bir "hoca” sıfatyla, Batı'dan bilim ve teknolojiyi getirerek onları, toplumun İslâmî dokusuna zarar vermeden ülkeye yerleştirme misyonu için Köse İmam'ın oğlu Âsım'ın şahsında yine gençliğe seslenir. Bu sesleniş de, tıpkı Fikret'in "Halûk'un Nesli"ne seslenişindeki gibi, yoğun bir pedagojik yönlendirme hususunu içerir:

“...Nerdesin hey gidi Berlin? diyerek yollanınız.

Alt ay, bir sene gayret size eğlence demek

Siz ki yıllarca neler çekmediniz, hem gülerek!

Hani, bir ömre bedeldir şu geçen her gününüz;

Bir gün evvel gidiniz, bir saat evvel dönünüz." (Ersoy 2007: 409-410)

Cumhuriyet döneminin ilk otuz yılında ise Kemalist kadro tarafindan öncülük edilen inkılapları veya bu inkılapların aksine olan ve ülkenin farkıı bir yönetim biçimi izlemesine dair yolları halka öğretmek ve aktarmak amacı, edebi metinlerde yansıma alanı bulur. Yakup Kadri, ütopik bir dünya kurduğu, Fredric Jameson'ın tabiriyle bir "ütopyacı program"ı (Jameson, 2009: 20) canlandırdığı Ankara romanında, Kemalizmin sosyo-ekonomik hedefleri net bir şekilde yansıma alanı bulur. Cumhuriyet'in 20. yılında "muasır medeniyetler seviyesi"nde bulunan gelişmiş bir Türkiye'yi, "sınıfsız ve imtiyazsız bir toplum"u buluruz. "Devrim şairi" olarak anılan Behçet Kemal Çağlar, "O İhtilâl Bayrağı" şiirinde, Mustafa Kemal Atatürk'ün izinden yürümeyi ve "Garplı kafa" ile "Türk gönül”ü birleştirerek ülkeyi Batılı medeni ülkelerle aynı seviyeye çıkarmayı gençliğe bir ödev olarak yükler:

"Ona ta can evinde yer vermeli insanlar.

Osmanlı anlayamaz onu, ancak Türk anlar:

Ateşinde erimek, yeniden şekle girmek,

-Ona ram olmak değil- biraz da olmak gerek;

Her haliyle örnek o Türk için erkek için;

Onu anlamışolmak ve onu sevmek için

Daralınca gönülde o azmi bulmak gerek;

Ona diz çökmek değil, ona doğrulmak gerek;

Şarklılık, Osmanlılık, gerilik bir tarafa!

Garplı kafa, Türk gönül; ak alın, olgun kafa...

İstediği hasada bu yerde rençberiz biz;

Onun 'Mustafa Kemal' dediği gençleriz biz!'(Çağlar 1938: 504-505)

Nâzım Hikmet ve ardılı toplumcu-gerçekçilerin, zaman zaman Jdanovcu bir çizgiye yönelerek, halkı sosyalizm hususunda eğittiği; Necip Fazıl ve Peyami Safa'nın ise dini-mistik duyarlılıkları okurlara anlatmayı ve onların inançlarını etkilemeyi hedefledikleri de 
bariz olarak ortadadır. Dolayısıyla öğretmen-yazar ile öğrenci-okur arasındaki ilişkinin 1950'lere kadar hemen hemen her edebi mecrada, şu veya bu şekilde, baskın olarak devam ettiğini, Gürsel Korat'ın deyişiyle söylersek, Türk edebiyatının bu süre zarfinda, bir yönüyle de olsa, "pedagojik" (Korat, 2013: 27) bir nitelikte bulunduğunu dile getirebiliriz.

1950'lere doğru ise Türk edebiyatında, gerek sosyo-ekonomik gerekse de estetik alanındaki gelişmelerden ötürü "öğretmen-öğrenci ilişkisi”nin yavaş yavaş ortadan kalktığını dile getirmek mümkündür. 1946 sonrası Türkiye'nin Bat kampına kesin olarak katılması, Truman Doktrini, Marshall Yardımı, NATO üyeliği, çok-partili sisteme geçiş gibi kapitalizmin hızı gelişmesine sebep olan etkenlerden ötürü, üstyapısal açıdan bir çözülme durumu ortaya çıkar. Bu çözülme durumu, Türkiye'deki hâkim düşünsel biçimde de yavaş yavaş bir değişikliğe sebep olur. Artk Doğu tipi despotik devlet felsefesinin ve inançların sosyal hayattaki belirleyici rolünün yavaş yavaş azalması, "mutlak metin"in giderek belirsiz bir duruma gelmesi ve kapitalist üretim biçimine uygun bir bireyci düşünselliğin öne çıkmasıyla birlikte edebiyat da "pedagojik" vasfinı yitirir. Ayrıca sürrealizm, varoluşçuluk gibi modern akımlar, bu dönemde etkisini evrensel düzeyde göstermeye başlar. Dolayısıyla bu yıllar, Türk edebiyat için bu açıdan bir dönüm noktasını da içerir. Gerek İkinci Yeni şairlerinin gerekse de 1950 kuşağı öykücülerinin ve romancılarının metinlerinde de görüldüğü gibi, öğretmen-yazar, yerini büyük oranda (Yusuf Atılgan, Ferit Edgü gibi yazarların; Cemal Süreya, İlhan Berk gibi şairlerin eserlerinde de görüldüğü gibi) yalnız, içe kapanık bireylerin yabancılaşma, absürtlük ve iletişimsizlikle dolu hayatlarını gösteren bir vizör konumundaki yazara, bir başka açıdan, "estetik obje" üreticisi yazara bırakır. Okur ise -yine büyük oranda- metni "kıssadan hisse" alınacak bir araç gibi görmekten çıkar; onun karşısında sadece estetik süje pozisyonunda bulunur. Dil de "göndergesel" olmaktan uzaklaşır ve çok-anlamlı bir yapıya kavuşur. Kısaca klasik yazar-okur ilişkisi, esasında bu yıllardan itibaren Türk edebiyat bağlamında tesis edilmiş olur.

Tam da bu noktada şu soru sorulabilir: "Baba-oğul ilişkisi", Tanzimat'tan Cumhuriyet'in ilk yıllarına kadar Türk aydınlarıyla ilgili olarak özellikle hangi hususlarda görülebilir? Bu bağlamda dile getirmek gerekir ki "baba-oğul ilişkisi", daha çok siyasi tasavvurlar ve pratikler etrafinda düşünülebilir. Nitekim Tanzimat'tan Cumhuriyet'in ilk yıllarına kadar Türk aydını, çoğunlukla, devlet ile birey arasındaki ilişki biçimini kurgulamada despotik Doğulu devlet felsefesi geleneğini anımsatan bir yapıyı öngörmüştür. Jön Türkler ve daha sonraki ìttihatçiler, "meşrutî monarşi"de karar kılmış; dolayısıyla padişahı devlet sisteminden dışlayacak bir siyasi yönetim biçimine pek de yönelmemişler ve dolayısıyla geleneksel padişah-tebaa ilişkisine yönelik bir yapıbozum çabasına girişmemişlerdir. Cumhuriyet dönemi aydınları da siyasi tasavvurlarında ve pratiklerinde hemen hemen aynı doğrultuda bir düşünce sergilemişlerdir. Yakup Kadri'nin Yaban romanındaki "çoban-sürü ilişkisi" metaforunda veya Kadro hareketinin bürokratik mekanizmanın hâkimiyetindeki sınıfsız-imtiyazsız toplum tasavvurunda da belirdiği gibi, güçlü bir devlet anlayışı bu dönem aydınlarının siyasi düşüncelerinde veya pratiklerinde belirgin bir öğe olarak konumlanmıştır. 


\section{SONUÇ}

Tanzimat'ın düşünsel evreninin “düalite”den çok Osmanlı'ya özgü Doğulu-i̇slâmî bir epistemolojik tandansı imleyen "mutlak metin"e dayalı olduğu; özellikle de bu dönem romanlarında söz konusu "mutlak metin"in ve "baba-oğul ilişkisi" metaforuyla açıklanabilecek bir ilişki biçiminin somutlaştiğı yönünde Jale Parla tarafindan ortaya konulan tezler, söz konusu dönemin aydınlarının ve edebiyatçılarının hem romanları hem de diğer eserleri göz önünde bulundurulduğunda son derece "aksak" durumdadır. Bu eserlerde Tanrı'nın varlığının akıl ile kanıtlanmaya çalışılması, ırkçı söylemlere başvurulması, kâinat ontolojisinin nizamsızlık eksenli düşünülmesi, yazarların/ediplerin bir "baskı" figüründen çok bir "ideolojik" figür olarak somutlaşması gibi hususları göz önünde bulundurmak, çalışma sırasında da görüldüğü gibi, Parla'nın tezlerindeki "aksaklığın" boyutlarını anlayabilmek için yeterlidir. Fakat son olarak şu hususu da belirtmek gerekir: Parla'nın tezlerinin "nihai nokta”sı Cumhuriyet'in bir “yanılgı"sı üzerinedir. Şöyle ki Parla, Tanzimat'ın düşünsel evreninin "düalite" şeklinde alımlanmasının bir "Cumhuriyet ideolojisi yorumu" olduğunu; böyle bir yorumun da "düalite"nin "Cumhuriyet'le en 'hayırlı' biçimde çözüldüğü yanılsamasından, ya da Cumhuriyetçiler'in kendi ikilemlerini önceki kuşaklara yansıtmalarından kaynaklanıyor olabil[-eceğini]"(Parla, 2016: 36) dile getirir. Bugün özellikle sosyokültürel alandaki çatışmalı durum görüldüğünde, Cumhuriyet'in söz konusu "düalite"yi "en "hayırlı biçimde" çözdüğü "yanılsamasına" sahip oluşunu imleyen tezde bir haklılık payı olduğu düşünülebilir. Fakat inceleme boyunca yapılan açıklamalardan da anlaşılabileceği gibi, "düalite"nin varlığına yönelik yapılan "yorum"un (Ziya Gökalp'ten Ahmet Hamdi Tanpınar'a kadar pek çok aydın bu "yorum"un en büyük temsilcileridir) doğru olarak okunabileceği; dolayısıyla Cumhuriyet aydınının sadece "kendi ikilemlerini" Tanzimat aydınlarına yansıtma çabasının sonucu olarak ortaya koyulan spekülatif bir yargı temelinde yükselmediği de barizdir. Aksini iddia etmek, Şinasi'den Namık Kemal'e; Hâmid'den Midhat Efendi'ye kadar pek çok aydın veya edibin eserlerini veya eserlerindeki fikir çatışmasını yok saymak olur. 


\section{KAYNAKÇA}

Ahmet Midhat Efendi (2003). Bütün Eserleri: Romanlar XII: Rikalda yahut Amerika'da Bir Vahşet Âlemi, Haz. M. Fatih Andı. Ankara: TDK Yayınları.

Althusser, Louis (2014). İdeoloji ve Devletin İdeolojik Aygıtları, Çev. Alp Tümertekin. İstanbul: İthaki Yayınları. Altuğ, Fatih (2014). "19. Yüzyıl Osmanlı Edebiyatında İmparatorluk, Medeniyet, Yerlilik, Yaban(cı)lık ve Din”, Tanzimat ve Edebiyat: Osmanlı İstanbul'unda Modern Edebi Kültür, Haz. Mehmet Fatih Uslu-Fatih Altuğ, İstanbul: Türkiye İ̧̧ Bankası Kültür Yayınları.

Bloom, Harold (2014). Bat Kanonu: Çağların Ekolleri ve Kitapları, Çev. Çiğdem Pala Mull. İstanbul: İthaki Yayınları.

Bloom, Harold (2008). Etkilenme Endişesi: Bir Şiir Teorisi, Çev. Ferit Burak Aydar, İstanbul: Metis Yayınları.

Çağlar, Behçet Kemal (1938), "O intilal Bayrağı”, Ülkü Halk Evleri Dergisi, C. 10, S. 60, Şubat 1938.

Ercilasun, Bilge (2006). "Servet-i Fünûn Edebiyatında Tenkit", Servet-i Fünûn Edebiyat, Haz. İsmail Parlattr. Ankara: Akçağ Yayınları.

Ersoy, Mehmed Âkif (2007). Safahat, Haz. M. Ertuğrul Düzdağ, İstanbul: Çağrı Yayınları.

Finn, Robert P. (2013). Türk Romanı: Illk Dönem, 1872-1900, Çev. Tomris Uyar. İstanbul: Agora Kitaplığı.

Foucault, Michel (1999). Bilginin Arkeolojisi, Çev. Veli Urhan. İstanbul: Birey Yayınları.

Göçgün, Önder (2009). Namık Kemal. Ankara: Atatürk Kültür Merkezi.

Gramsci, Antonio (2014). Hapishane Defterleri, Çev. Adnan Cemgil, İstanbul: Belge Yayınları.

Jameson, Fredric (2009). Ütopya Denen Arzu. Çev. Ferit Burak Aydar. İstanbul: Metis Yayınları.

Kaplan, Mehmet (2007). Şiir Tahlilleri 1. İstanbul: Dergâh Yayınları.

Korat, Gürsel (2013). Kristal Bahçe. İstanbul: İletişim Yayınları.

Küçük, Yalçın (1990). Aydın Üzerine Tezler 1, İstanbul: Tekin Yayınevi.

Lyotard, Jean François (1984). The Postmodern Condition: A Report on Kowledge, Trans. Geoff BenningtonBrian Massum, Manchester: Manchester Univ. Press.

Moran, Berna (2010). Türk Romanına Eleştirel Bir Bakış 1: Ahmet Mithat'tan A. H. Tanpınar'a. İstanbul: Illetişim Yayınları.

Parla, Jale (2016). Babalar ve Oğullar: Tanzimat Romanının Epistemolojik Temelleri. İstanbul: İletişim Yayınları. Pospelov, Gennady N. (2005). Edebiyat Bilimi, Çev. Yılmaz Onay. İstanbul: Evrensel Basım Yayın.

Sağlam, Nuri (2013). "Modernleşme Dönemi Türk Edebiyatının Siyasî ve Toplumsal Misyonu”, Sabah Ülkesi, S.34.

Şeyh Galip (2000). Hüsn ü Aşk, Haz. Orhan Okay-Hüseyin Ayan. İstanbul: Dergâh Yayınları.

Şinasi (2005). Bütün Eserleri, Haz. İsmail Parlatrr-Nurullah Çetin. Ankara: Ekin Kitabevi.

Tanpınar, Ahmet Hamdi (1977). "Türk Edebiyatında Cereyanlar", Edebiyat Üzerine Makaleler, Haz. Zeynep Kerman. İstanbul: Dergâh Yayınları.

Tevfik Fikret (2010). Rübâb-ı Şikeste ve Diğer Eserleri, Haz. Fahri Uzun. İstanbul: İnkılâp Kitabevi. 